\title{
The Use of Remote Sensing Data to Zoning Catchments in Flood Control Efforts in Banjarbaru
}

\author{
Lalu Heriyadi Surya ${ }^{*}$, Wahyuni Ilham², Arfa Agustina², Susilawati² \\ 1 Department of Natural Resources and Environmental Management, Postgraduate Program, Lambung Mangkurat \\ University, Banjarbaru, Indonesia 70714 \\ 2 Department of Forestry, Faculty of Forestry, Lambung Mangkurat University, Banjarbaru, Indonesia 70714 \\ *Correspondence: psdal.unlam@gmail.com
}

\begin{abstract}
This Research was occupied due to the frequent flood disaster in Indonesia especially in Banjarbaru city. South Kalimantan's Research and Development Council in 2010 stated that the largest endangered flood are from spatially classification was Bangkal Village in Banjarbaru City. It became necessary to control by doing area zonation which determine the recharge area. This research was conducted survey method and data analysis by using information overlay from Geographic Information System. This research resulted the recommended recharge zone width was 2801,7 ha. In this research zone, the researchers gained 9 group of recharge zone and the development plan or activities to do. The researchers also configured some flooding potential classification, vary from 0,064 $\mathrm{m} /$ second to $0,078 \mathrm{~m} / \mathrm{second}$. The flooding water could be dried in at last 9,127 hours. The flood controlling efforts in settlement area biopores application and recharge wheel, for the water bodies were rivers normalization, planting trees or fruits and medical plants in buffer area. Social approach also could empowered the Bangkal Village Society with clean and sustainable environment competitions, environmental extension course about waste economic value and waste bank management.
\end{abstract}

Keywords: recharge area, Geographic Information System, overlay, zonation, flood control

\section{Introduction}

This research was based on the frequent occurrence of natural disasters in Indonesia, specifically the flood around Banjarbaru. The results of the research from the Balitbangda of South Kalimantan 2010 stated that the most extensive Bangkal Urban Village, Banjarbaru City was spatially classified as an area that was very prone to flooding. Control efforts are needed, one of which is zoning areas that can be used as water catchment areas (recharge area). This research uses survey and data analysis methods with remote sensing based on geographic information systems.

This research uses survey and data analysis methods with remote sensing based on geographic information systems. The data and information needed and analyzes the data in accordance with the needs and research purposes. The stages include four parts, namely (1) Stage of digital image processing, (2) Field measurement stage, (3) Data and zoning analysis phase, and (4) Interview stage and filling out the questionnaire form

This study aims to determine the zoning of water catchment areas in Bangkal Village, Cempaka District, Banjarbaru City, South Kalimantan, determine the efforts or efforts that can be developed and are useful in flood control in the Bangkal Sub-District of Banjarbaru, South Kalimantan.

\section{Research Methods}


This study uses survey methods and data analysis that is needed to collect data and information needed and analyze data according to the needs and objectives of the study. While the stages, namely (1) digital image processing (2) field measurement process, (3). Data and zoning analysis phase and (4) interview questions and filling out the form.

\section{Results and discussion}

\section{Utilization and remote sensing for identification of land cover}

Rice fields are the most extensive land cover among 8 existing land coverings. Next is open land and forests. Rice fields with an area of $30.62 \%$, open land $23.86 \%$ and forests 23.51 . Settlements have an area of at least 8 existing land cover. Settlement area is $1.25 \%$.

\section{Utilization of remote sensing data for infiltration measurements}

Based on the map of the type of land in the Banjarbaru city in 2012, there are 12 types of land in the new Banjar city area. Whereas there are 5 types of land in Bangkal village. The type of soil is Eutrudepts Udifluvent Endoaquepts, Endoaquepts Sulfaquentes, Endoaquepts Dystrudepts (Sulfic), Kanapapults Haplodux Endoaquods, Kandiudox Hapludox Kanhapludults.

Measuring point the infiltration rate is determined based on soil type and land cover. First, the thematic layer / map of the type of land obtained from the city of Banjarbaru and the land cover layer resulting from the analysis and interpretation of Quickbird images is prepared. The next step is to overlay with GIS's software help for the two layers. The overlay process produces 40 units of land. From the land unit table, it is known that 3 types of land cover are not measured, namely road bodies, paddy fields and water bodies, because of these three land cover are considered impermeable to water saturated water and it is not possible to do infiltration measurements using a double ring infiltration meter. From 3 land cover, 15 units of land were formed which were not taken as samples. The remaining 25 sample points are given attributes to take samples.

\section{Relationship between infiltration parameters}

a. Infiltration of Ess soil types (endoaquepts sulfaquents)

b. Infiltration of Esc soil type (sulfic endoaquepts)

c. Infiltration of Eue soil type (Eutrudepts Udifluvents Endoaquepts)

d. Infiltration of Khk soil types (Kandiudox Hapludox Kanhapludults)

e. Infiltration of Khe soil types (Kanhapludults Hapludox Endoaqouds)

\section{Water Catchment Zone}

Determination of this water catchment area uses one technique in spatial analysis namely the Overlay technique.

\section{Water Control Efforts}

\section{Development of water catchment areas}

After the zoning of the water catchment area for Bangkal village has been obtained, from the zone there can be development of each regional tier whether it can be recommended or not as a water catchment area based on several reference parameters, including:

1. Proximity to the main road: if the water catchment zone is close to the road there is a possibility that the zone will change from the current condition, because there will be a high probability of being used by the land owner for residential buildings or business land.

2. Height factor: this allows the development of several types of plants that can be developed for water catchment areas.

3. Soil pH factor: relates to policies to develop plant species that are adjusted to the similarity of the land.

4. Factor proximity to settlements: this allows the development of green open spaces and infiltration wells

The above factors are used as a reference for the zone of water catchment area and after grouping it based on the 4 criteria above, nine zoning water catchment areas are obtained and the reference is for development. Development for zoning 7 is the widest of the 9 zones. While for zoning 5 is the smallest area, namely the development of green open space and infiltration wells. This is related to the area of settlements which is at least compared to other land cover. 
Development of residential land and water bodies in flood control efforts can be done in various ways, including: the development of biopores, buffering of rivers and planting trees or plants that are beneficial to the community.

\section{Social Community approach}

Social efforts can be made by mobilizing the level of community participation in maintaining river banks.

Urban village officials can take the initiative to form a group of independent waste management groups such as waste banks that can manage community waste so that it can be more useful for example in making compost and liquid fertilizer. This can be done by mobilizing counseling that gives the message that waste can be of economic value.

In an effort to control floods, city governments need to pay attention to the efforts of structures in flood control, such as river normalization and protection of river embankments.

River normalization efforts can be carried out by continuing efforts to protect the river embankment by developing buffer areas on the dadap river bank, namely by planting trees or fruit trees that are useful and of economic value.

\section{Historical and cultural approaches}

The name of this kelurahan is Bangkal (Khairurrijaal, 2012). According to stories from local people, the name of the Bangkal is sour from the word Bangkal which originated from the Bangkal tree. Based on the stories of local residents from generation to generation, the name Bangkal was given because in this region there are many Bangkal trees.

Bangkal tree or yellow bangkal Nauclea subdita (Korth.) Steud. In Indonesia known by the name bangkununing, male bangkal, cangcaratan (Sunda), Kingdom: Plantae (plants), subkingdom: Tracheobionta (vascular plants) super division: spermatophyte (produce seeds) division: Magnoliophyta (flowering plants), class: Magnoliopsida (in two pieces / dikotil), SubClass: Asteridae, Order: Rubiales, Family: Rubiaceae (coffee-copy tribe), Genus: Nauclea, Species: Nauclea subdita (Korth,) Steud.

Banjar culture knows Bangkal tree as an additional ingredient in making cold pupur. The part of the skin is mashed and made as a natural yellow dye which gives the effect of helping the process of exfoliating the epidermis and extra fragrance (Sumandari, 2010). Based on observations in the field, it is known that there are still Bangkal trees in this village, which have historically been closely related to the place of growth. The author considers that the potential of Bangkal tree to be developed as an icon of Bangkal village is very large. The community in this village can be directed to plant on their own land. Like the yard of the house and the area of rice fields, as well as buffer areas on the banks of the river. The first positive value that can be obtained is the potential for the cultural development of the Banjar tribe who have the habit of wearing cold pupur. The effort to maintain and preserve Bangkal trees which are the ingredients for cold pupur. The effort to preserve and preserve Bangkal trees, which are the ingredients for making cold mushrooms, has contributed to preserving the Banjar culture.

The second is the benefits of Bangkal trees in an effort to help the land to absorb water. Bangkal trees have deep roots and are able to live in flooded areas. With roots in this bangkal tree will help the soil by informing more and more pore pores. With many pores, it functions in improving the texture and structure of the soil which is useful in the process of absorbing water into the soil. The better soil conditions in absorbing water in Bangkal urban village will help efforts to control flooding in this region.

\section{REFERENCES}

Arifin, Yudi Firmanul. 2006. Faktor Penyebab Banjir dan Kebakaran Hutan dan Lahan Berdasarkan Analisis Data Perubahan Penutupan Lahan dan Iklim di Kalimantan Selatan. Lembaga Penelitian Lingkungan Hidup. Lembaga Penelitian Universitas Lambung Mangkurat. Banjarbaru.

Asdak, Chay. 2007. Hidrologi dan Pengelolaan Daerah Aliran Sungai. Gadjah Mada University Press. Bandung.

Badan Penelitian dan Pengembangan Daerah Provinsi Kalimantan Selatan, 2010 Masterplan Banjir dan Pengelolaannya di Kalimantan Selatan, Banjarmasin.

Badan Perencanaan Daerah dan Penanaman Modal Kota Banjarbaru, 2012. Laporan Profil Infrastuktur Kota Banjarbaru Tahun 2012. 
Badan Pusat Statistik, 2012. Kota Banjarbaru dalam Angka. Badan Pusat Statistik Banjarbaru, Banjarbaru.

Badan standardisasi Nasional, 2010. Klarifikasi Penutup Lahan. Standar Nasional Indonesia. SNI 7645:2010. Jakarta.

Departemen Pertanian Republik Indonesia, 1980. Kriteria Fungsi Kawasan (Lampiran 2). Jakarta

Ekadinata, Andree. Dewi, Sonya. Hadi, Danan Prasetyo. Nugroho, Dudi Kurnia. Johana, Feri. 2008. Sistem Daya Alam. Buku 1. Sistem Informasi Geografis dan Penginderaan Jauh Menggunakan ILWIS Open Source. Bogor.

GIS Konsorsium Aceh Nias, 2007. Modul Pelatihan ArcGis Tingkat Dasar. Banda Aceh, 26 Maret s/d 5 April 2007. Nangroe Aceh Darussalam.

http://raharjabayu.wordpress.com/2011/06/25pengukuran. Minggu 20 April 2014 20:09

http://www.plantamor.com/index.php?plant=1471. Minggu 20 April 2014 19:51

khairurrijaal. 2012. Profil Kelurahan Bangkal. Pemerintahan Kota Banjarbaru Kecamatan Cempaka Kelurahan Bangkal. Banjarbaru.

Prahasta E, 2008. Remote Sensing : Praktis Penginderaan Jauh \& Pengolahan Citra Dijital dengan Perangkat Lunak ER Mapper. Informatika Bandung, Bandung.

Purba, Mahardika Putra, 2009. Besar Aliran Permukaan (Runn-Off) Pada Berbagai Type Kelerengan di Bawah Tegakan Eucalyptus Spp. (Studi Kasus di HPHTI PT Toba Pulp Lestari, Tbk. Sektor Aek Nauli. USU Medan, Skripsi.

Rahman, Abdur. 2010. Analisis Campuran Spektral Secara Linier (LSMA) Citra Terra Modis untuk Kajian Estimasi Limpasan (Studi Kasus Sub DAS Riam Kanan dan sekitarnya). Tesis.

Sudadi, Purwanto. 1996. Menentukan Parameter Daerah Peresapan Air dalam Kaitannya dengan Keputusan Menteri Negara Lingkungan Hidup Noo 39/MENLH8/1996. Jurnal.

Sumandari, Dwi retno. 2010. Bedak Dingin (Pupur Bangkal). Program Pasca sarjana Magister Pendidikan Ilmu Pengetahuan Sosial. Universitas Lambung Mangkurat. Banjarmasin. Makalah.

UNESCO. 2007. Petunjuk Praktis. Partisipasi Masyarakat dalam pengelolaan Banjir. UNESCO office. Jakarta.

Utomowati, Rahning. 2006. Pemanfaatan Citra Landsat 7 Enhanched Thematic Mapper untuk Penentuan Wilayah Prioritas Penanganan Banjir Berbasis Sistem Informasi Geografis (SIG), FKIP Universitas Sebelas Maret Surakarta.

Waryono, Tarsoen. 2008. Peranan Kawasan Resapan Air. Kumpulan Makalah Periode 1987-2008. Jakarta.

Wibowo, Mardi. 2006. Model Penentuan Kawasan Resapan Air untuk Perencanaan Tata Ruang Berwawasan Lingkungan, Jakarta.

Wadartono, Barandi Sapta. 2002. Petunjuk Praktikum SIG (Aplikasi SIG II) Lab Sistem Informasi Geografis. Fakultas Geografi. UGM. Yogyakarta.

Wiwoho, Bagus Setiabudi. 2008. Analisi Potensi Daerah Resapan Air Hujan di Sub DAS Metro Jawa Timur. Jurnal. FMIPA. Universitas Negeri Malang. Surabaya. 